\title{
Progressive steps in understanding and solving guava wilt - a national problem*
}

\author{
A.K. MISRA \\ Central Institute for Subtropical Horticulture, Rehmankhera, Lucknow 226 101, Uttar Pradesh, India
}

Received: 10 December 2016/ Accepted: 20 February 2017/ Published online: 23 March 2017

(C) Indian Phytopathological Society 2017

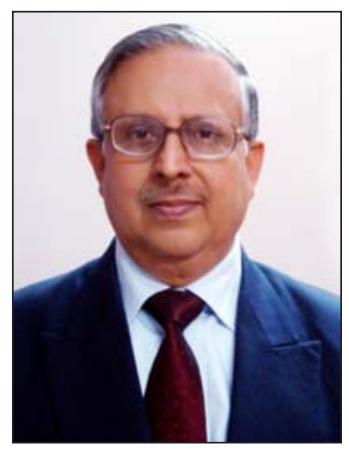

Keywords: Disease management, epidemiology, Fusarium oxysporum f.sp. psidii, Guava wilt, Psidium guajava

At the outset, I wish to convey my gratefulness to all the members of the Indian Phytopathological Society for unanimously electing me as President of this prestigious Society. I pay my tributes to all the eminent Plant Pathologists of India and past Presidents of the Indian Phytopathological Society, who have nurtured the society, brought international recognition for the society and contributed significantly for the subject. I feel humble and privileged to deliver this presidential lecture for the year 2015. I have selected a subject in which I have spent more than 20 years of my active research period i.e. guava wilt, which is a ticklish problem.

Guava (Psidium guajava Linn.) is one of the important fruits of our country. It is called poor man's apple, as it is nutritious and cheap and available in all places. In India it is grown in an area of approximately 268 thousand ha with a total production of 3668 thousand MT and average productivity of $13.7 \mathrm{MT} / \mathrm{ha}$ (Annonymous, 2015). It is an easily grown crop in all types of soil and almost in all the states of India with highest area in U.P. (45.0 thousand ha), followed by Maharashtra (40.0 thousand ha) and Bihar (30.0 thousand ha). It is a hardy crop and is cultivated even near river bed also. Highest productivity is reported from Madhya Pradesh i.e. 37.6 MT/ha. The productivity is low in U.P. i.e. only $13.4 \mathrm{t} / \mathrm{ha}$, which is mainly due to heavy incidence of wilt disease. The true Allahabad Safeda variety seems to have disappeared from famous Allahabad guava area and its divergent types are now available. The average productivity can at least be doubled, if wilt disease is managed effectively. Efforts to manage wilt by chemical means generally fail. Work in last two decades at $\mathrm{CISH}$, Lucknow revealed that the disease can be effectively managed, if complete package of integrated disease management practices are followed, which include use of resistant root stock,

${ }^{*}$ Presidential Lecture delivered at $68^{\text {th }}$ Annual Meeting of Indian Phytopathological Society and $6^{\text {th }}$ International Conference on "Plant, Pathogens and People" on 23-27, February, 2016 at NASC Complex, New Delhi

Email:misra_a_k@yahoo.co.in biocontrol, intercrop with cultural practices and resistant varieties. Complete wilt management schedule is available and needs to be implemented in totality.

\section{Historical background and geographical distribution}

In India, guava (Psidium guajava Linn.) is grown almost in all the states. Wilt of guava was first reported in 1935 from Allahabad. To understand the disease initial work was done at Allahabad Agricultural Institute, Naini under the leadership of Dr. J.C. Edward and at Bidhan Chandra Agriculture University, Kalyani under the leadership of Prof. S.B. Chattopadhyay. In recent past efforts were made to understand the disease at ICAR-CISH, Lucknow and ICAR-RCER, Ranchi. In a networking project with the headquarter at ICAR-CISH, Lucknow and 5 SAUs (NDUA\&T, Faizabad, CSAUA\&T, Kanpur, SVBPU, Meerut, SHIATS, Naini and GBPUA\&T, Pantnagar) information of guava wilt was generated on the understanding and practical aspects of the disease for disease management. The work on this problem was reviewed from time to time by Misra and Prakash (1990), Misra (1995, 2001, 2003, 2005), Misra and Pandey (1996), Negi et al. (2001) and Gupta et al. (2010). After the first report of guava wilt in 1935 from Babakkarpur, Allahabad, it was reported from different parts of U.P. by several workers (Das Gupta and Rai, 1947; Dey, 1948; Anonymous, 1949, 1950; Prasad et al., 1952; Mathur, 1956; Edward and Srivastava, 1957; Singh and Lal, 1953; Pandey and Dwivedi, 1985; Misra and Prakash, 1986; Misra, 1987). After the first few reports from U.P. and West Bengal, the disease was reported from several other places i.e. from Haryana (Suhag, 1976; Mehta, 1987), Punjab (Chandra Mohan et al., 1986), Rajasthan (Katyal, 1972; Bhargava et al., 2003), Delhi state (Anonymous, 1953), Jhakhand (Srivastava et al., 2001), Andhra Pradesh (Jhooty et al., 1984) and M.P. (Personal observation), Orissa and Tamil Nadu (Personal observation).

Wilt in guava plants have also been reported from other countries viz. Florida, USA (Webber, 1928), Taiwan 

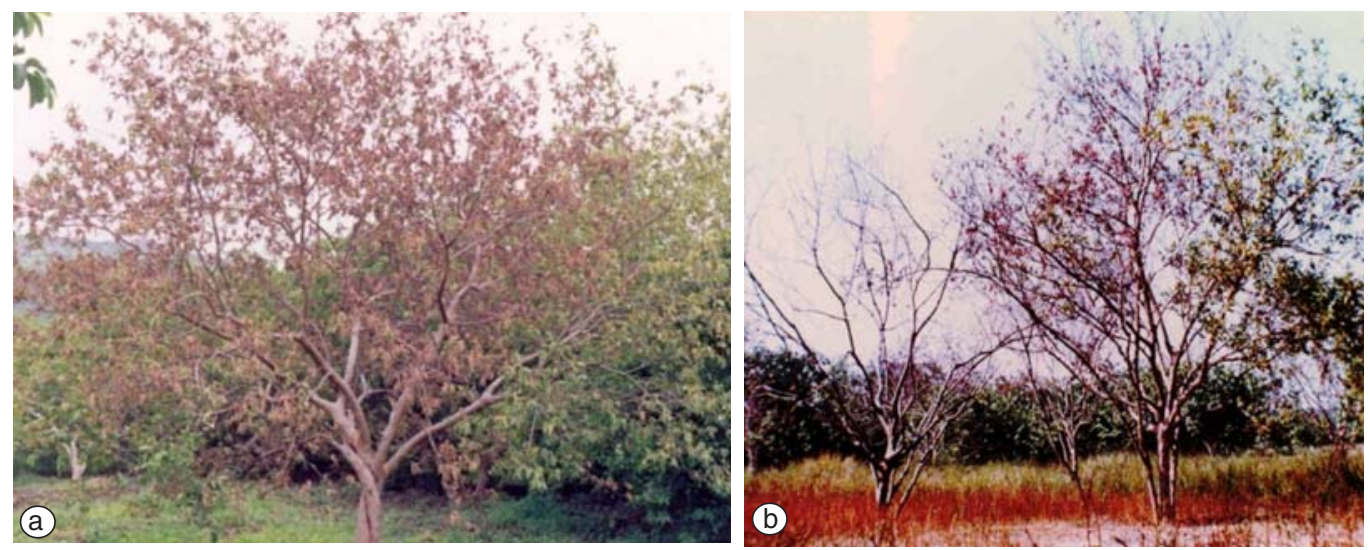

Fig. 1. Symptoms of (a) complete quick wilt and (b) partial wilt

(Hsieh et al., 1976; Leu and Kao, 1979), Cuba (Rodrigvez and Landa, 1977), South Africa (Grech, 1985; Vos et al., 2000), Brazil (Tokeshi et al., 1980; Rodriguez et al., 1987; Junqueira et al., 2001), Pakistan (Ansar et al., 1994), Bangladesh (Hamiduzzaman et al., 1997), Canberra and Australia (Lim and Manicom 2003).

\section{Losses}

Loss assessments due to wilt disease in guava were estimated in different terms by different workers. Singh and Lal (1953) estimated 5-15 per cent loss amounting to almost 1 million rupees due to guava wilt every year in 12 districts of U.P. In West Bengal, the disease reduced the yield by 80 per cent (Chattopadhyay and Sen Gupta, 1955). Land value reduced to half by the presence of the disease in Andhra Pradesh (Jhooty et al., 1984). About 150 and 300 acres of guava orchards in Punjab and Haryana respectively were uprooted during 1978-81 due to heavy incidence of guava wilt (Jhooty et al., 1984). In U.P. the famous guava area of Unnao, Gangaghat and Bithoor are now no more guava dominated area. It is replaced by annual crops. Around Lucknow loss due to wilt in guava varied from 5-60 per cent (Misra and Shukla, 2002).

\section{Symptoms}

Symptoms of wilt in guava is generally confusing. Any guava plant dying cannot be termed as wilt. It is necessary to discriminate the two i.e. wilt and death of plant. Death of the plant may be due to heavy infestation of insect-pests like stem borer, bark eating caterpillar, termite or root white grubs. It can also be due to root rotting fungi like Pythium, Phytophthora, Rhizoctonia or Macrophomina or it can be due to cultural reasons/water deficiency or physiological or soil reasons. It is also to be understood that guava wilt is a disease of grown up plants and not the disease of guava seedlings or young guava plants. True wilt is that, when the xylem vessels are affected and movement of water and nutrition is restricted and finally plants die. Xylem vessels are blocked with the physical presence of pathogen mycelium/spores, gums or formation of tylose etc. or effect of toxin production by the pathogens. Hence, it is essential to understand the basic concept before studying the wilt in guava.

Wilt affected plants show varied symptoms, but it can be grouped into two major symptoms i.e., slow and quick wilt. Quick wilt can be termed as true wilt and plants take 2 weeks to two months period for the complete wilting, after the appearance of first visible symptom. In slow wilt, plants take about a year or more for complete wilting. Sometimes partial wilting also takes place, which is a typical symptom of wilt in guava. Initially, one side or some portion show symptoms and later on the other half is affected.

When we describe the symptom of true wilt, the affected plants show sudden drooping of leaves with yellow colouration. At the later stage shedding of leaves take place. Twigs become bare and fail to bring forth new leaves or flowers and eventually dry up. Fruits of all the affected branches remain underdeveloped, become hard, black and stony and remain on branches for some time. Later the entire plant becomes defoliated and eventually dies (Fig. 1a). Some trees show only partial wilting and only half or some portion wilt and other half remain healthy, which wilt later. This type of partial wilting is common in guava and is a typical symptom of guava wilt (Fig. 1b). It was found in our studies that in quick wilt, it requires only sixteen days (minimum) for complete wilting of the plant, after the appearance of first visible symptom. Some affected trees linger on and even takes about a year to wilt (Misra and Pandey, 2000b). We also studied variations in the symptoms during different months of the year and noticed yellowing of the leaves with intervenial chlorosis during the month of August. At this stage, the leaves drop even with the slight shaking of the plants. During September, general drooping of the leaves takes place. During October complete wilting of plants are seen with almost dried leaves and small dried black fruits hanging (winter crop) on the branch. It is also recorded that some plants show wilting of variable degree (leaf yellowing, drooping of leaves, drying of terminal branches or partial wilting) during different months but later escape/ resist wilting. These plants start recovering from December onward. It was recorded that out of total wilting plants, around 17 per cent plants, which initially show 
some symptoms of wilting, ultimately escape/resist wilting (Misra and Pandey, 2000b).

The finer roots show black streaks, which become prominent on removing the bark (Das Gupta and Rai, 1947). The roots also show rotting at the basal region and the bark is easily detachable from the cortex. The cortical regions of the stem and root show distinct discoloration and damage. Light brown discoloration is noticed in vascular tissues (Chattopadhyay and Bhattacharjya, 1968a,b). Wilted plants later show bark splitting. The pathogen attacks young as well as old fruit bearing trees but older trees are more prone to the disease (Misra and Shukla, 2002).

\section{Causal organism}

Various pathogens are reported as causal organism by different workers but only some may be causal organism, while others are merely associated with the affected plants. The reported pathogens by various workers are Fusarium oxysporumf. sp. psidii, F. solani, Macrophomina phaeseoli, Rhizoctonia bataticola, Cephlosporium sp., Gliocladium vermoesenii; Gliocladium roseum and Verticillium albo-atrum and Acremonium sp. (Vestal, 1941; Dey, 1948; Das Gupta and Rai, 1947; Prasad et al., 1952; Edward and Srivastava, 1957; Pandey and Dwivedi, 1985; Chattopadhyay and Bhattacharjya, 1968a,b; Chattopadhyay and Sengupta, 1955; Chandra Mohan, 1985; Pandey and Dwivedi, 1985 and Sohi, 1983a,b; Misra and Pandey, 1997 and Misra and Pandey, 2000a).

The reports from other parts of the world are different. Clitocybe tabescens, Myxosporium psidii, Septofusidium sp., Penicillium vermoensenii, Colletotrichum gloeosporiodes, Fusarium oxysporum $\mathrm{f}$. sp. psidii, Meloidogyne sp., Helicotylenchus sp., Pratylenchus sp., Pseudomonas sp., Erwinia psidii are reported by various workers (Webber, 1928; Rodriguez and Landa, 1977; Hsieh et al., 1976; Leu et al. 1979; Tokeshi et al., 1980; Rodrigues et al., 1987; Jungueira et al., 2001; Grech, 1985; Ansar et al., 1994; Hamiduzzaman et al., 1997; Vos et al., 2000; Lim and Manicom, 2003). It is possible that one or more pathogens may be responsible for the disease. Some may help as cofactor or predisposing factor for the wilt syndrome. Gomes et al. (2011) advocated that the guava decline/wilt can be characterized as a complex problem, caused by the synergistic effect of these organisms, in which parasitism by the nematodes also predispose the plants to root decay and then entry of pathogen.

Seeing the complexity of problem and association of various pathogens, work was initiated at ICAR-CISH, Lucknow to confirm the pathogens. Programme was initiated for isolation of pathogens and proving their pathogenicity. For proving the pathogenicity, it was felt necessary to standardize the inoculation technique. As guava wilt is a disease of grownup plants (more than 5 years of plants), seedlings cannot be used for proving the pathogenicity as they do not give true picture. Hence, there was need to develop technique to reproduce the

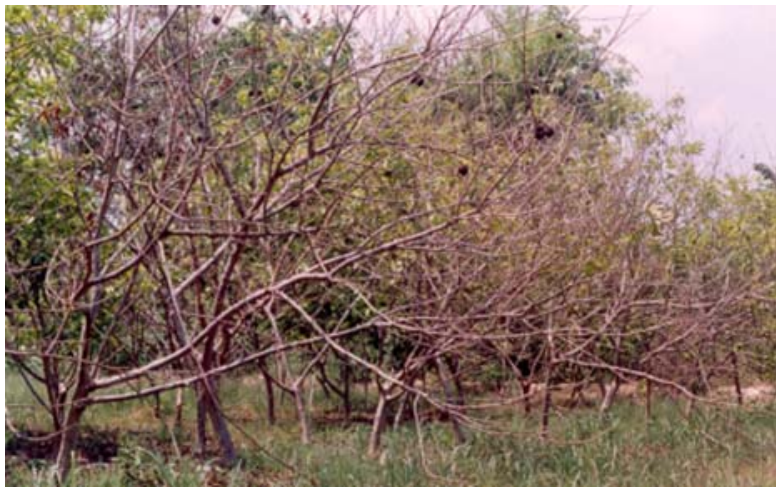

Fig. 2. Guava plants (5-6 years old) inoculated in field by stem hole inoculation technique with Gliocladium roseum, reproduced the symptom

disease in grownup plants. Among the different techniques such as soil, root and stem hole inoculation for the reproduction of wilt, the stem hole inoculation technique proved most successful and quick in reproducing the symptoms. In this inoculation technique, 2-3 $\mathrm{cm}$ deep hole was made in main trunk, $8-10 \mathrm{~cm}$ above the ground level with the help of carpenter's drill of $3 \mathrm{~mm}$ diameter and different cultures were placed separately in the hole with the help of sterilized needle, covered with sterilized moist cotton swab and tied with polythene band. Observation on wilting was recorded at regular intervals. July and August months were found suitable period for inoculation, when' humidity is high due to onset of monsoon (Misra and Pandey, 2000a). Further at ICAR$\mathrm{CISH}$, Lucknow it was revealed that Gliocladium roseum as one of the pathogens of guava wilt, which reproduces symptom of wilt on artificial inoculation besides other pathogens (Misra and Pandey, 1997; Misra and Pandey, 2000a) (Fig. 2).

In a massive isolation programme at ICAR-CISH isolations from different places yielded 43 fungal isolates. Pathogens dominated in isolation were Fusarium oxysporum, F. solani, F. pallidoroseum, F. decemcellulare, F. equiseti, Gliocladium roseum, G. virens, $G$. penicilloides, Acremonium sp., A. restrictum, Curvularia lunata, C. pallescens, Chloridium virescens and Pestalotiopsis dissieminata (Misra and Pandey, 1999). Some were causal organism, while others were only associated with the disease. Later, Fusarium oxysporum f. sp. psidii, F. solani, Gliocladium roseum, G. virens, G. penicilloides, Acremonium sp. caused wilting in pathogenicity test and were consistently re-isolated from affected tissue, thus fulfilling Koch's postulates. Later, Gliocladium virens, Acremonium sp. inoculated plants regenerated after showing initial symptoms. Hence, only Fusarium oxysporum f. sp. psidii, F. solani, Gliocladium roseum, $G$. penicilloides were considered as the causal organism for wilt in guava. Gliocladium virens and Acremonium sp. were grouped as week pathogen.

Later again in a survey two new species of Fusarium viz. Fusarium proliferatum and Fusarium chlamydosporum were found associated with this disease. However, pathogenecity of Fusarium 
chlamydosporum was successfully proved in a field trial. The culture of $F$. chlamydosporum was processed for DNA sequencing and DNA sequence was submitted to NCBI with GenBank accession no. HM102506. The submitted DNA sequence of $F$. chlamydosporum was compared for the genetic position in Fusarium spp. evolutionary phylogenic tree (Gupta and Misra, 2012).

Again in an extensive survey and isolation from severely wilt affected area, Fusarium oxysporum f. sp. psidii and the F. solani were isolated most frequently (Misra, 2008) and can be considered as the real pathogen of guava wilt causing typical wilt. The other pathogens are also responsible, but with lesser frequency. It was also found that out of the two pathogens, the frequency of F. solani was more compared to Fusarium oxysporum f. sp. psidii (Misra, 2008). In the collection of 176 isolates it was found that the isolates of Fusarium oxysporum $\mathrm{f}$. sp. psidii and F. solani collected from different places showed great variability. These cultures were deposited at ICAR NBAIM, Mau (Misra, 2008).

In a lab studies, it was found that Fusarium oxysporum f. sp. psidii and F. solani are highly variable pathogens. Cultural and physiological (temperature and $\mathrm{pH}$ ) data revealed that maximum mycelial growth was obtained in potato dextrose agar as semi-solid media, while malt extract broth as liquid broth media. Maximum sporulation was recorded in oat meal agar and mycological broth. The optimum temperature and $\mathrm{pH}$ for growth of both Fusarium spp. isolates was $28^{\circ} \mathrm{C}$ and 5.5 . The isolates differed in their colony growth; mycelial mass, macro-conidia, and micro-conidia production (Gupta et al., 2010a). The isolates of F. oxysporum f. sp. psidii, and F. solani were grouped on the basis of various morphological characters viz. colony colour, texture, colour of metabolite released, frequency of their occurrence on culture, sporulation and macro-conidia production and type/percentage of wilting they caused. High degree of variations is probably the reasons for the variable degree of incidence and severity of the disease in different places of our country.
Relative pathogenic ability was assessed in 50 Fusarium isolates [F. oxysporum f. sp. psidii (14), F. solani (32), F. chlamydosporm (2) and F. moniliforme (2)] and a non-pathogenic isolate of $F$. oxysporum from banana. Of these, $24 \mathrm{~F}$. solani isolates produced wilt symptoms either on both replicates or on a single plant showing 61 per cent wilt. Out of 14 , only 8 isolates of F. oxysporum f. sp. psidii caused wilt in both the replicates and five showed 75 per cent wilt only in one plant. Interestingly, both the isolates of $F$. chlamydosporm were pathogenic but the two isolates of $F$. moniliforme and the non-pathogenic isolate of $F$. oxysporum could not cause wilt in guava plants. It was noticed that different isolates caused wilting at a variable period of time indicating difference in their relative aggressiveness or virulence. Earliest symptom of wilt was recorded in isolates $\mathrm{F} 6$ ( $F$. chlamydosporm), F9 and F26 (F. solani), and F50 (F. oxysporum f. sp. psidii). Isolate F9 ( $F$. solani) was found as the most virulent (Misra and Gupta, 2010).

Partial sequencing of F. oxysporum f. sp. psidii isolate VKGF01 (HM102500), F. solani isolate VKGFS1, VKGFS2 (HMI02502 and HM102503) and $F$. chlamydosporum isolate VKGFC01 (HM102506) were also done.

Total 36 representative isolates of $F$. oxysporum $\mathrm{f}$. sp. psidii (6 from one location) and 36 representative isolates of $F$. solani ( 6 from one location) collected from 6 different agro climatic zones/guava growing areas of India were subjected to molecular characterization. Out of twenty RAPD primers screened, OPM 11(RBM3) was found best to produce good allelic band with all isolates of F. oxysporum f. sp. psidii and F. solani. Product size ranged from 200 bps to 2000 bps and 600 bps was obtained almost in all the isolates of Fusarium spp. For F. solani RAPD data were subjected to construct a dendogram using UPGMA software. It showed that isolates from Agra and Farukhabad regions were almost identical and form one group. Punjab and Ranchi region isolates formed second group. F. solani, isolates of Allahabad region were distinctly related to isolates of other regions (Fig. 3).

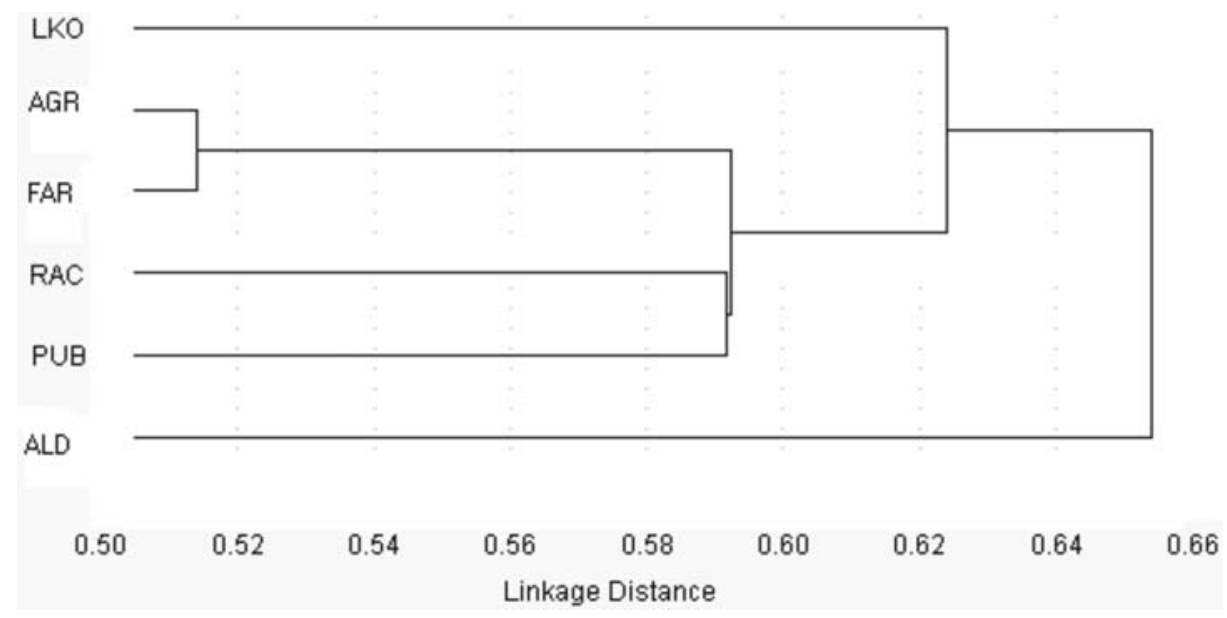

Fig. 3. Dendogram derived from Randam Amplified Polymorphic DNA analysis of six isolates of Fusarium solani of six different regions. The bottom scale is the percentage of similarity (LKO - Lucknow, AGR - Agra, FAR - Farukhabad, RAC - Ranchi, PUB - Punjab, ALD - Allahabad) 
Dendrogram with Homology Coefficient \%:0.0 (UPGMA)

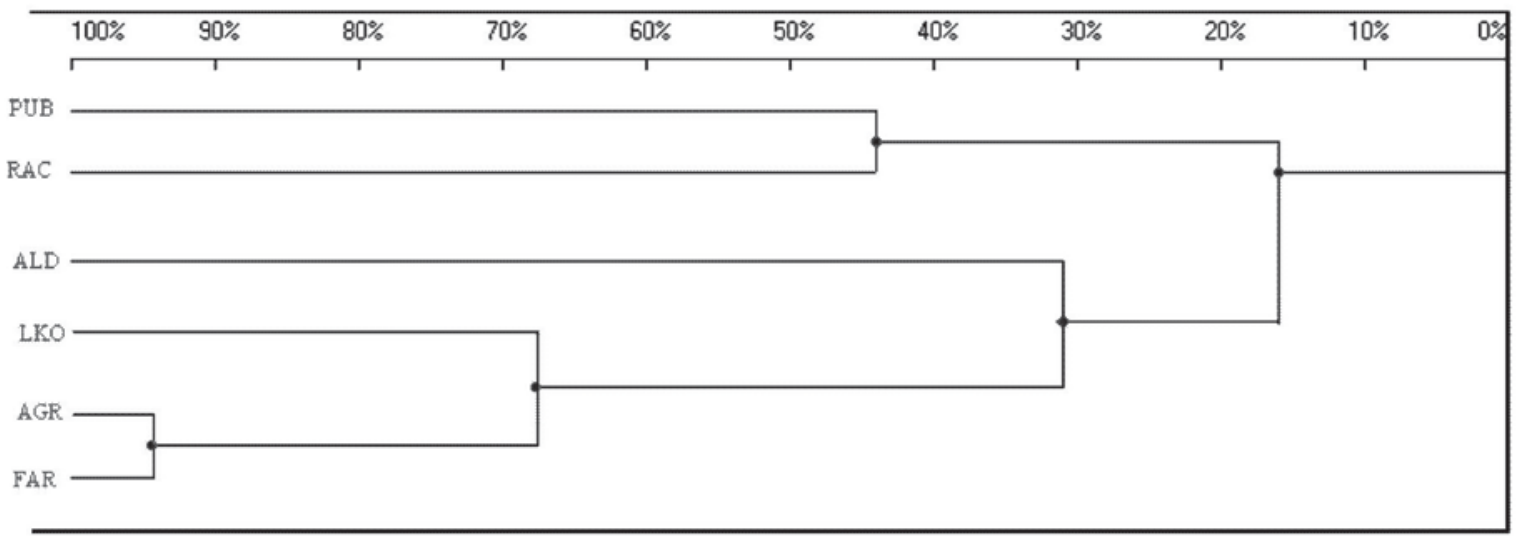

Fig. 4. Dendogram derived from Randam Amplified Polymorphic DNA analysis of six isolates of F. oxysporum f. sp. psidii of six different regions

Similarly, for F. oxysporum f. sp. psidii , RAPD data were subjected to construct a dendogram using UPGMA software. It showed that isolates from Agra and Farukhabad regions were almost similar and formed one group. Punjab and Ranchi region formed second group (Fig. 4).

Six representative isolate of Fusarium solani, collected from different places of India were subjected to analysis of genetic variability in terms' of Carboxylesterases isozyme pattern and DNA polymorphism using RAPD-PCR. Pattern of Carboxyl esterase revealed a similar isozyme cluster in the isolate namely, Allahabad (isolate-S), Faizabad, (isolate-d). Unnao (isolate-S) and Lucknow (isolate-6). Similar results were obtained when 10 randomly amplified polymorphic DNA markers (OPA I-OPA 10) tested in the genome of Fusarium solani and grouped on basis of obtained allelic data. This pattern of genetic variability in the isolates was also supported by the analysis of the similarity indices and UPGMA dendrograrri (Gupta et al., 2009).

Further, comparative molecular analysis of Fusarium solani isolates by RFLP and RAPD was done. Seven representative isolates of $F$. solani were collected from different places of India and analysed by restriction fragment length polymorphism (RPLP) using HindIII or Dral restriction endonucleases and random amplified polymorphic DNA (RAPD). Pattern of restriction enzyme revealed a similar restriction cut type cluster in isolates namely, Allahabad (isolate-B), Faizabad (isolate-4), Unnao (isolate-S) and Lucknow (isolate-S) region, while other cluster consisted of isolates from Ranchi (isolate2) and Ludhiana (isolate-7). Slightly variable results were obtained when 10 randomly amplified polymorphic DNA markers (OPAOI-OPAIO) were tested in the genome of Fusarium solani and grouped on basis of obtained allelic data. RAPD fingerprinting showed a higher variability than RFLP, and each isolate had a unique electrophoretic pattern with five of the ten primers used. Results showed that RAPD is much efficient to distinguish all F. solani isolates (Gupta et al., 2010b).

Assessment of genetic diversity of Fusarium solani from different agro-ecological regions of India was also done by Misra et al. (2013). A phylogenetic tree based on RAPD data was generated showing the three major clades. Additionally, specific primer set was used for detection of $F$. solani and all tested isolates showed positive result in PCR assay.

The association of nematode Heliocotylenchus dihystera was found higher in the field of affected orchards and is considered to enhance the incidence of wilt (Khan and Misra, 2003). It was interpreted that Heliocotylenchus dihystera make the entry point in guava root for the pathogen. Recently, Meliodogyne spp. was also found associated with the disease in some localities of Badayu (U.P.). On enquiring the details, it was found that this Badayu area had history of growing vegetables, which had problem of root gall nematodes. The soil has developed very high build up of Meliodogyne spp. Under the heavy pressure of this nematode population slow death of plants takes place. Hence, it can be said that Meliodogyne spp. cause death of the plant and not wilt. This may be termed as other problem responsible for slow death of plants.

\section{Epidemiology}

There is clear picture on the period of higher disease incidence during the year. Extensive studies on the progress of natural wilting of guava plants during different months have been made. Misra and Pandey (1999d, $2000 b$ ) at Lucknow found that wilting generally start after rains during August, September and maximum wilting occur during October month. Some plants, which show slight yellowing start recovering from December onwards. On analyzing the weather data, it was found that higher rainfall during July-September with maximum temperature ranging from 31.3 to $33.5^{\circ} \mathrm{C}$ and minimum temperature ranging from 23 to $25^{\circ} \mathrm{C}$ and humidity around 76 per cent favour the wilt incidence. It was also found that two months are required for the complete wilting of plants (from appearance of $1^{\text {st }}$ visible symptom to complete wilting). However, minimum period was found only 16 days. There are variable reports about the severity of disease at different $\mathrm{pH}$ levels and variable fertilizer levels. However, the disease is common in different types 


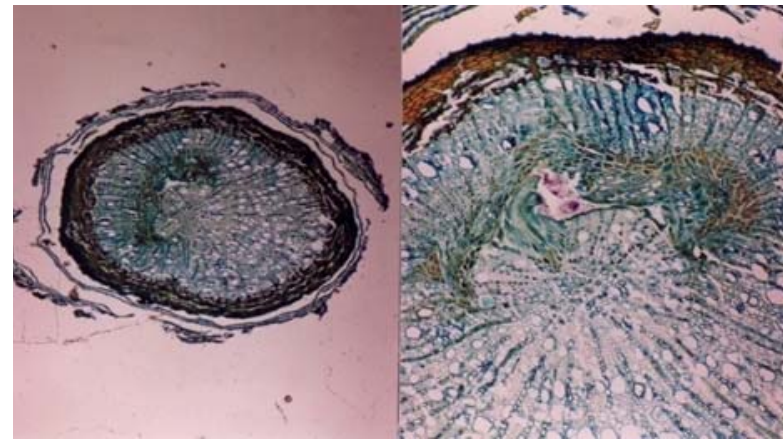

Fig. 5. T.S. of diseased root showed disintegration of epidermis and cortex and necrosis of vascular tissue

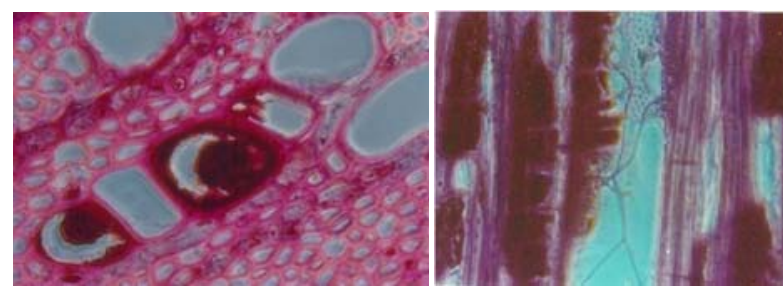

Fig. 6. TS and LS of stem showing tyloses and fungal mycelium causing blockage of vessels

of soil and at different $\mathrm{pH}$ or different levels of fertilizers. Hence, it cannot be correlated either with soil types or $\mathrm{pH}$ or different levels of fertilizers etc.

\section{Histopathology}

Histopathological studies of the root samples revealed breaking and opening in the epidermis, through which pathogens are supposed to enter in the host tissue (Fig. 5). Necrosis in the internal tissue and vascular bundle were recorded, which restricts the movement of water and nutrient in the plant and thus results in wilting of guava plants.

Physical presence of the pathogen and tylose formation was also recorded in the root tissues, which restrict the movement of water and nutrition in the plant (Fig. 6).

\section{Disease management}

Time to time recommendations for the control of guava wilt has been suggested by different workers. These are summarized below.

\section{Disease management through chemicals}

Different chemical managements have been suggested by different workers. Chaubatia paste, water-soluble 8Quinolinol sulphate, benlate or bavistin, metasystox and zinc sulphate, thiophanate methyl, captafol and thiabendazole were suggested (Anonymous, 1949; Jain, 1956; Suhag, 1976; Bhargava et al., 2003; Leu et al., 1979). In South Africa tebuconazole, propiconazole, prochoraz, triforine and carbendazim + flusilazole were found effective in vitro evaluation (Joubert and Frean, 1993). Misra and Pandey (1999b) reported that though different fungicides viz. bavistin, topsin M, indofil M-45, thiram, blitox check the various wilt pathogens in laboratory effectively, but these pathogens increase their aggressiveness with profuse spore mass production in the soil, once the effect of these fungicides diminishes in soil (Misra and Pandey, 1999), and hence cannot be recommended. These chemicals are costly and repeated application is not economical also. Moreover, seeing the soil mass, increasing aggressiveness of the pathogen, profuse spore production and economics, chemical management does not seem practical.

Besides fungicides, some soil amendment chemicals/cakes/fertilizers were also evaluated for control of wilt. Mathur et al. (1964) found wilt control by soil treatment with $1.82 \mathrm{~kg}$. lime or gypsum/tree, although the control mechanism was not well understood. Oil cakes like neem cake, mahua cake, kusum cake supplemented with urea @ $10 \mathrm{~kg}$ and $1 \mathrm{~kg}$ respectively also check the disease (Das Gupta and Ghoshal, 1977). At ICAR CISH, Lucknow it was found that wilt could be checked by application of $6 \mathrm{~kg}$ neem cake $+2 \mathrm{~kg}$ gypsum per plant (Misra and Pandey, 1994-95). These can be integrated as one of the components in the integrated disease management practices.

\section{Disease management through cultural practices}

Mathur (1956) advocated that wilt could be controlled by proper sanitation in the orchard. Wilted trees should be uprooted, burnt and trench should be dug around the tree trunk. Edward (1960a) suggested that while transplanting, roots of plants should not be severely damaged. Maintenance of proper tree vigour by timely and adequate manuring, inter-culture and irrigation enable them to withstand infection. The pits may be treated with formalin and kept covered for about 3 days and then transplanting should be done after two weeks. Prasad et al. (2003), Khan and Misra (2003), Misra, 2004 and Misra et al. (2004b) reported intercropping with turmeric or marigold could restrict the wilting of guava. Misra (2016) also observed that the orchards, which were having frequent tillage, had more incidence of wilt compared to less tilled orchards. Tillage during monsoon enhance wilt incidence (personal observation). During a conversation with a guava farmer at Lucknow, it was informed that he does not allow tillage in guava orchard during monsoon period and afterwards till December. Hence, tillage should be avoided during monsoon and afterwards till December. As the disease is soil borne in nature, flood irrigation spreads the disease. Hence, separate basin irrigation or drip irrigation should be encouraged for the management of disease. These cultural practices are useful and should be adopted for integrated management practices as important component.

\section{Disease management through varietal resistance and root stock}

Edward (1961) reported cultivar Chittidar, Hafsi, Safeda Riverside, Rolf and Stone acid susceptible and guava species Psidium cattleianum var. lucidium and other 


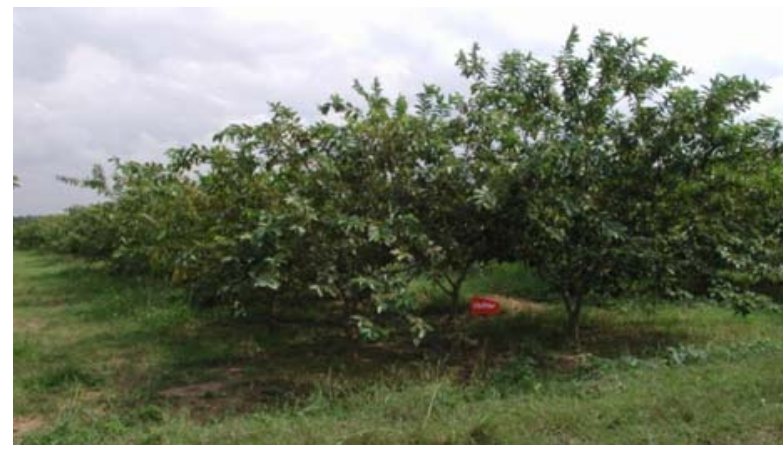

Fig. 7. Guava cv. Chittidar, resistant to wilt

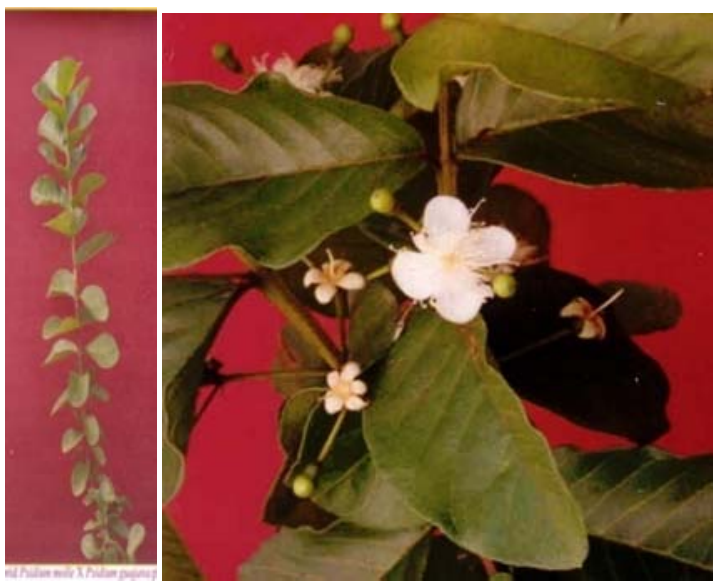

Fig. 8. Root stock Psidium molle X Psidium guajava (F1) free from wilt

genera Syzigium cumini (Jamun) resistant to wilt. Edward and Gaurishanker (1964) further reported that Syzigium cuminii, Lagerstraemia indica, Psidium cattleianum (Psidium molle), $P$. quianense, Chinese guava $(P$. friedrichsthalianum) and Philippine guava are resistant to wilt. The strawberry guava (Psidium cattleianum) has been reported relatively hardy species from Reunion (Normand, 1994). At ICAR CISH, Lucknow, Misra (199899) studied the relative field tolerance of 20 guava cultivars and categorized them into different groups on the basis of their natural susceptibility. The cultivars Allahabad Safeda, Florida Seedling, Guinees, Hafsi, Karela, Mirzapuri Seedling, Nasik, Pear Shaped, Sindh, Superior and White Fleshed proved highly susceptible; Behat Coconut and Pourtgal as susceptible; Apple Colour, Chittidar, Seedless, Spear Acid, Superior Sour Lucidium, Red Flesh and Smooth Green as tolerant. The cv. Chittidar is graded as reasonably good cultivar, which has reasonable level of resistance as well as good quality and taste and can directly be used as resistant material (Fig. 7).

Stock-scion compatibility was also evaluated. When cv. Safeda as scion and the resistant material reported by Edward and Gaurishanker (1964) i.e. Syzigium cuminii, Lagerstraemia indica, Psidium cattleianum (Psidium molle), $P$. quianense, Chinese guava ( $P$. friedrichsthalianum) and Philippine guava) as rootstock were evaluated, Lagerstraemia indica proved incompatible, Syzigium cumini (Jamun) as partially compatible and other guava species as compatible. They suggested use of resistant rootstock as a possible means for management of guava wilt. Later, at ICAR CISH Lucknow, Misra (2004) again tried Syzigium cumini (Jamun) as root stock and found late incompatibility with scion, although for few months scion survived on this root stock, but could not pickup growth. Further working on the root stock, Misra et al. (2003c) identified F1 population of Psidium molle $X$ Psidium guajava free from wilt (Fig. 8), when grown in wilt sick plot and inoculated repeatedly with Gliocladium roseum, Fusarium solaniand Fusarium oxysporum. This is compatible root stock with any variety of guava which can be multiplied on it. This material is now used at $\mathrm{CISH}$, Lucknow as resistant root stock for multiplying plants of choicest variety of guava.

\section{Disease management through bioagents}

As wilt pathogens are primarily soil borne, it is desired that any management material, which multiples itself in the soil, is more useful for the management of the disease. The chemicals (fungicides) do not fulfill this requirement. The effects of chemicals are also hazardous for the soil and environment, moreover when the effect of chemicals diminishes, the pathogens develop resistance and become more virulent and aggressive (Misra and Pandey, 1999b). Hence, considering the above facts, it was considered more desirable to use the bioagents for the management of the wilt disease of guava.

At ICAR-CISH, Lucknow three bio-agents were found effective for the management of the wilt disease i.e. Aspergillus niger strain AN 17, Trichoderma harzianum and Penicillium citrinum (Misra et al., 2000,2004; Prakash et al., 2002) (Fig. 9). When these

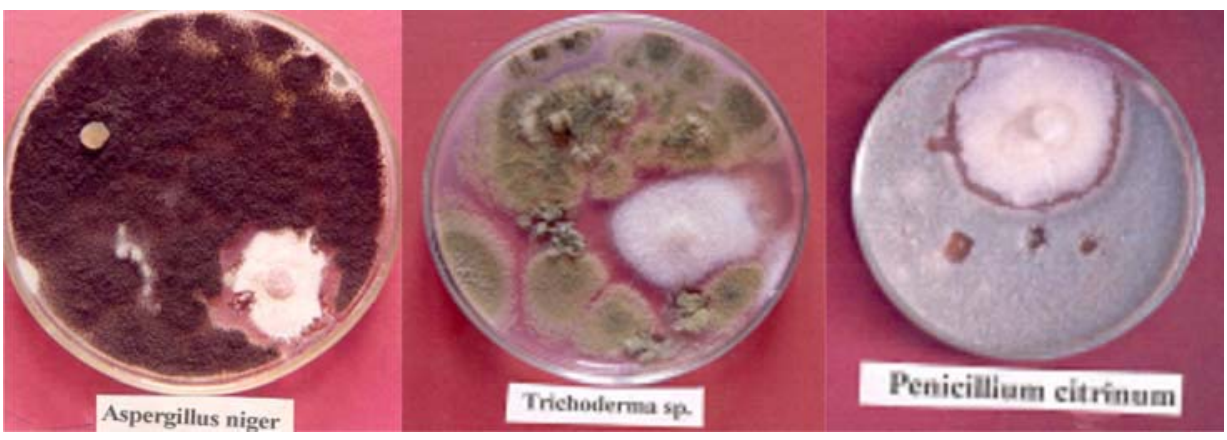

Fig. 9. Aspergillus niger strain AN 17, Trichoderma harzianum and Penicillium citrinum as bioagent 


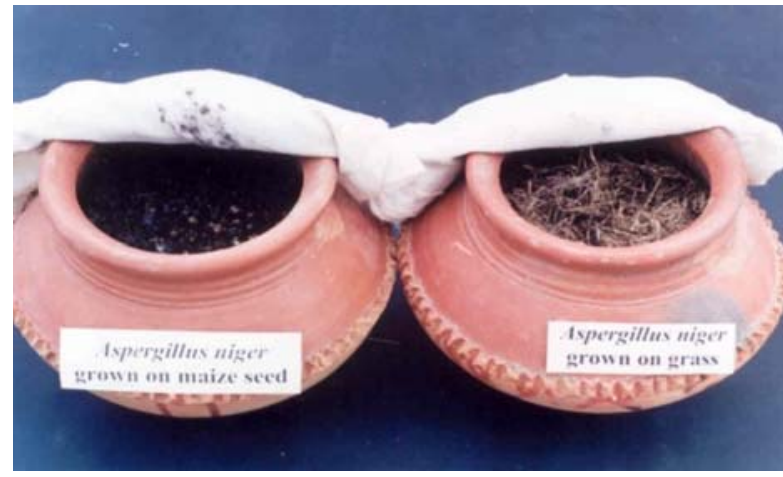

Fig. 10. Multiplication of Aspergillus niger in earthen pots

fungi were tested for the management of wilt pathogen in laboratory conditions, these were found quite effective (Misra et al., 2004).

When relative growth of the three bio-agents was studied, it was found that Aspergillus niger AN17 was fastest growing and most effective in controlling the wilt disease in field (Misra, 2004; Misra and Prasad, 2003). Besides this quality, it is also growth enhancer and the plants treated with Aspergillus niger AN17 developed faster with more height, more thickness and more numbers of leaves (Misra et al., 2000). These can be grown easily on any substrate like maize/bajra seeds etc. and can also be multiplied on cheap substrates like Sacchrum sp. (grass) and dry and green leaves of Psidium guajava (Shukla et al., 2003). It was also found that at village level these bioagents can be multiplied even in earthen pots (Misra and Prasad, 2004) (Fig. 10).

Technique of mass multiplication of bio-agents (Fig. 11) and application in the field were standardized (Misra, 2004; Misra et al., 2003b,d; Misra and Singh, 2005) and is summarized below:

\section{Method of multiplication of Aspergillus niger}

- $\quad$ First the culture of Aspergillus is multiplied on maize seed in bottles.

- Then it is further multiplied in FYM.

- $\quad$ FYM bed is prepared of known quantity $(1 \mathrm{~m} \times 2 \mathrm{~m} \times$ $30 \mathrm{~cm})$.

- $\quad$ Multiplied culture is added to bed @ 0.1 per cent i.e $1 \mathrm{~g} / \mathrm{kg}$ of FYM (Fig. 11).

- Light amount of water is sprayed over the bed to increase moisture and covered with polythene sheet.

- After 4-5 days, it is reopened and again light amount of water is sprayed and FYM is turned properly for mixing it and again covered with polythene sheet.

- $\quad$ This process is repeated 3-4 times to allow A. niger to multiply in FYM properly.

\section{Method of application of Aspergillus niger}

- While planting the new guava plants, each pit is filled with $5 \mathrm{~kg}$ of this enriched FYM with $A$. niger and then the new guava plant is planted in this pit.
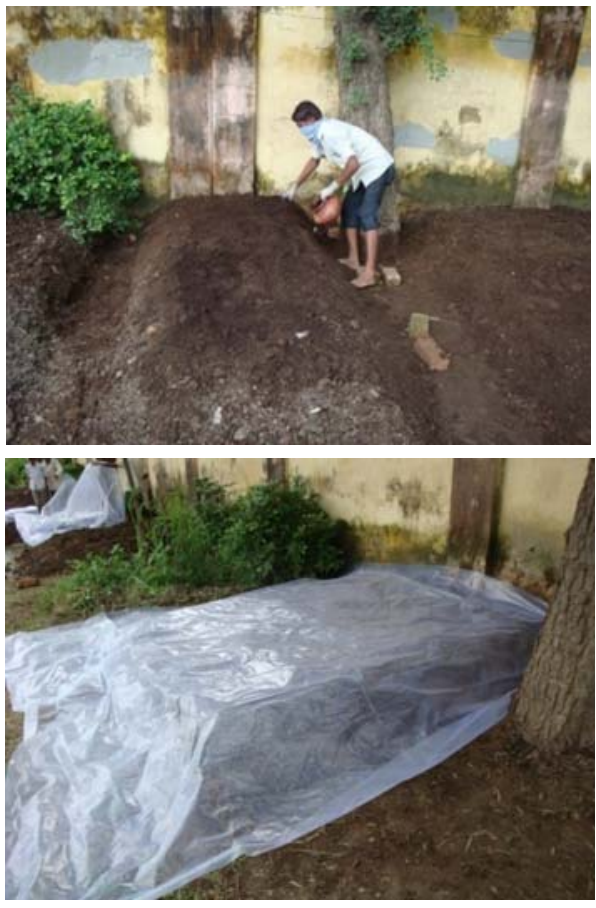

Fig. 11. Mass multiplication of bio-agents in FYM

- In grown up plants, $10 \mathrm{~kg}$ of this enriched FYM is added near the root zone of guava plants and properly mixed in soil by turning the soil and mulched with organic mulch.

- This practice is repeated every year in the month of June end as preventive measure.

Similarly the other bio-agents viz. Trichoderma harzianum and Penicillium citrinum can also be multiplied and applied.

\section{Integrated eco-friendly approach}

Considering the complexity of the problem, integrated eco-friendly approach for the management of guava wilt was suggested by Misra et al. (2003c, 2004b) and Misra (2005).

- Use resistant root stock (P. molle x P. guajava).

- $\quad$ Apply bioagent (Aspergillus niger, Trichoderma spp. or Penicillium citrinum) at the time of planting and regularly once every year in form of enriched FYM before monsoon.

- Intercropping with marigold or turmeric.

- Application of neem cake and gypsum.

- Minimum tillage. Avoid tillage at least during monsoon.

- Separate basin irrigation or drip irrigation.

- Maintain plant population.

- Maintain sanitation in orchard.

It is very necessary to implement complete management practice so that effective management is achieved. Following only one or two components do not 
give desired result. If disease is managed the production of guava can easily be doubled.

\section{CONCLUSION}

- Disease is complex.

- Several pathogens may cause wilt of guava, However, Fusarium oxysporum, F. solani, F. clamydosporum, Gliocladium roseum are important pathogens.

- Role of nematode is in aggravating the disease.

- Frequency of $F$. solani was found more common.

- G. roseum was found aggressive pathogen.

- Degree of severity depends on the pathogen and strain.

- Minimum tillage should be done in guava field especially during monsoon/after rain.

- Flood irrigation to be avoided. It should be either basin irrigation or drip irrigation.

- Complete Integrated Disease Management practice need to be adopted for the effective management of disease.

- Bioagents (fresh self prepared) need to be applied every year with FYM.

- Practical and long lasting solution lies with resistant root stock (Psidium molle $x$ P. guajava)/cultivar.

- Maintenance of plant population is a practical solution and the gap made by wilted plant immediately be filled.

- In West Bengal crop rotation has proved effective, where plant growth is fast and 5-6 years old plants gives good yield.

\section{REFERENCES}

Anonymous (1949). Annual Administrative Report of the Department of Agriculture, United Provinces for the year 1947-48. 89 pp.

Anonymous (1950). Annual Administrative Report of the Department of Agriculture, United Provinces for the year ending 30th June, 1949. 125 pp.

Anonymous (1953). Report of the Directorate of Plant Protection, Quarantine and Storage for the period 1946 1951. Govt. of India Press, Delhi. 44 pp.

Annonymous (2015). Indian Horticulture Database 2014 (Ed. Chander P. Gandhi), Pub. National Horticulture Board, Ministry of Agriculture, Government of India, Gurgaon, India.

Ansar M, Saleem A and lqbal A (1994). Cause and control of guava decline in Punjab (Pakistan). Pakistan $J$. Phytopathology 6: 41-44.

Bhargava AK, Sobti AK and Ghasolia RP (2003). Studies on guava (Psidium guajava L.) drying/wilt disease in orchards of Pushkar Valley. J. Phytological. Res. 16: 81 -84.

Chandra Mohan (1985). Studies on guava decline in Punjab with special reference to wilt. Ph.D. Thesis, Punjab Agric. Univ., Ludhiana, India, $90 \mathrm{p}$.

Chandra Mohan, Jhooty JS and Chand T (1986). Prevalence of guava decline in Punjab. Plant Dis. Res. 1: 77-78.
Chattapadhyay SB and Bhattacharjya SK (1968a). Investigations on the wilt disease of guava (Psidium guajava L.) in West Bengal I. Indian J. Agric. Sci. 38: 6572.

Chattapadhyay SB and Bhattacharjya SK (1968b). Investigations on the wilt disease of guava (Psidium guajava L.) in West Bengal II. Indian J. Agric. Sci. 38: 176183.

Chattopadhyay SB and Sengupta SK (1955). Studies on wilt of Psidium guajava L. in West Bengal. Indian J. Hort. 12: 7679.

Das Gupta MK and Ghoshal BK (1977). Is it possible to control guava wilt through oil cake amendments? Sci. and Cult. 43: 131-133.

Das Gupta SN and Rai JN (1947). Wilt disease of guava ( $P$. guajava). Curr. Sci. 16: 256-258.

Dey PK (1948). Plant Pathology, Adm. Rep., Agric. Dept., U.P., 1945-46, 43-46 pp.

Edward JC (1960a). Wilt disease of guava. The Allahabad Farmer 34: 289-293.

Edward JC (1961). Root stock trials for guava wilt control. The Allahabad Farmer 35: 5-9.

Edward JC and Gaurishanker (1964). Rootstock trial for guava (Psidium guajava L.). The Allahabad Farmer 38: 249-250.

Edward JC and Srivastava RN (1957). RE 502 - Studies on guava wilt. The Allahabad Farmer 31: 144-146.

Grech NM (1985). First report of guava rapid death syndrome caused by Septofusidium sp. in South Africa. Plant Dis. 69: 726.

Gomes VM, Souza RM, Mussi-Dias V, Silveira SFD and Dolinski C (2011). Guava decline: A complex disease involving Meloidogyne mayaguensis and Fusarium solani. J. Phytopathol. 159: 45-50.

Gupta VK and Misra AK (2012). Fusarium chlamydosporum causing wilt disease of guava (Psidium guajava L.) in India. Archives of Phytopathology and Plant Protection (Taylor and Francis), pp. 1-4.

Gupta VK, Misra AK, Gaur R, Pandey R and Chauhan UK (2009). Studies of genetic polymorphism in the isolates of Fusarium solani. Aust. J. Crop Sci. 3: 101-106.

Gupta VK, Misra AK, Gaur RK, Jain PK, Gaur D and Sharma S (2010). Current status of Fusarium wilt disease of guava (Psidium guajava L.) in India. Biotechnology 9: 176-192.

Gupta VK, Misra AK and Gaur RK (2010a). Growth characteristics of Fusarium spp. causing wilt disease in Psidium guajava L. in India. J. Plant Prot. Res. 50: 430440.

Gupta VK, Jain PK, Misra AK, Gaur R and Gaur RK (2010b). Comparative molecular analysis of Fusarium solani isolates by RFLP and RAPD. Microbiology 79: 772-776.

Hamiduzzaman MM, Meat MB and Ahmad MU (1997). Effect of Fusarium oxysporum and nematode interaction on guava wilt. Bangladesh J. PI. Pathol. 13: 9-11.

Hsieh SPY, Liang WJ, Kao CW and Lau LS (1976). Morphological and physiological characters of Myxosporium psidii, the causal organism of guava wilt. Plant Prot. Bull. (Taiwan) 18: 309-317.

Jain SS (1956). A preliminary note on the inactivation of Fusarium oxysporum f. psidii in guava plants by chemotherapeutic treatment. Indian J. Hort. 13: 102-104.

Jhooty JS, Chand JN and Krishnamurthy V (1984). Report of committee constituted by ICAR on guava decline in Punjab and Haryana. Submitted to ICAR, New Delhi. 
Joubert MH and Frean RT (1993). An in vitro evaluation of fungicides against guava wilt. Inligtingsbulletin Instituut Vir Tropiese en Subtropiese Gewasse (246): 3.

Junqueira NTV, Andrade LRM de, Pereira M, Lima MM and Chaves R da C (2001). Diseases of guava (Psidium guajava L.) cultivated in Brazilian Cerrdos. Circular Tecnica Embrapa Cerrados (15): 31.

Katyal SL (1972). Twenty five years of research on fruit crops. Indian Farming 22: 14-16.

Khan RM and Misra AK (2003). Influence of co-cultivation of marigold, garlic and turmeric on nemic population in guava cropping system. Souvenir \& Abstract, Zonal Conference (East Zone), Indian Society of Mycology and Plant Pathology \& Seminar on Plant Diseases of National Importance with Special Reference to Guava Wilt and Mango Malformation. 4-5 $5^{\text {th }}$ April, 2003. CISH and IISR. Lucknow. 24-25 pp.

Leu LS and Kao CW (1979). Artificial inoculation of guava with Myxosporium psidii. Plant Dis. Rept. 63: 1077-1079.

Leu LS, Kao CW, Wang CC, Liang WJ and Hsieh SPY (1979). Myxosporium wilt of guava and its control. Plant Dis. Repotr. 63: 1075-1077.

Lim TK and Manicom BQ (2003). Diseases of guava. In: Diseases of tropical fruit crops. pp. 275-289. (Ed. Ploetz, RC). Pub. CABI, Wallingford, U.K.

Mathur RS (1956). Guava diseases in India. Indian J. Hort. 13: 26-29.

Mathur RS, Jain SS and Swarup J (1964). Chemical treatment for guava wilt. Proc. Natn. Acad. Sci., India. Sect B. 34: 3336.

Mehta N (1987). Distribution of guava wilt in relation to age, soil type, management practices and varieties grown in Haryana. Plant Dis. Res. 2: 116-119.

Misra AK (1987). Studies on diseases of fruits crops. Annual Report, ClHNP, Lucknow. pp. 124 -125.

Misra AK (1995). Guava Wilt. In: Advances in Diseases of Fruits in India. (ed. S.J.Singh), Kalyani Publishers, Ludhiana, pp. 183-190 + I plate.

Misra AK (1998-99). Screening against wilt. Annual Report, CISH, Lucknow, 10pp.

Misra AK (2001). Diseases of Guava and their Management. In: Diseases of Fruits and Vegetables and their Management (Ed. Thind TS), Kalyani Publishers, Ludhiana, pp 128-138.

Misra AK (2003). Guava diseases-their symptoms, cause and Management. In: Diseases of fruits and vegetables: Diagnosis and management. Vol. 2 (Ed. Naqvi SAMH). Pub. Kluwer Academic Publishers, The Netherlands. pp 81-119.

Misra AK (2004). Final Report, Networking project on investigation on guava wilt with special reference to etiology and management (UPCAR/UPDASP Word Bank Project). Submitted to UPCAR, Lucknow.

Misra AK (2005). Important diseases of guava in India with special reference to wilt. Souvenir. Ist International Guava Symposium. December 5-8, 2005. CISH, Lucknow. pp. 7590.

Misra AK (2008). Important diseases of guava and their management. In: Souvenir, National Guava Symposium. Improvement, Production and Utilization. $24^{\text {th }}-26^{\text {th }}$ Nov. 2008. Guava Grower Association, Shiridi, AMPUS, Pune, $\mathrm{CISH}$, Lucknow and MPKV, Rahuri. pp. 8-14.

Misra AK (2008). Final Report, Networking project on wilt of crops with special reference to cultural, morphological, molecular characterization and pathogenic variability of isolates of India (Guava wilt) (ICAR project). Submitted to Networking PI - IIPR, Kanpur and ICAR, New Delhi. p. 70.

Misra AK (2016). Progressive steps in understanding and solving guava wilt - a national problem. Presidential address. Abstracts $6^{\text {th }}$ International Conference on Plant, Pathogens and People. $23^{\text {rd }}-27^{\text {th }}$ Feb. 2016. Indian Phytopathological Society, New Delhi. pp. 8.

Misra AK and Gupta VK (2010). Relative pathogenicity of Fusarium wilt isolates to guava (Psidium guajava L.). J. Mycol. PI. Pathol. 40: 72-77.

Misra AK and Pandey BK (1994-95). Studies on Guava wilt. Annual Report, CIHNP, Lucknow. 28 pp.

Misra AK and Pandey BK (1996). Present status of wilt disease of guava. In: Disease Scenario in Crop Plants. Vol. I - Fruits and Vegitables. (Eds. Agnihotri VP, Prakash Om, Kishun Ram and Misra AK). International Books and Periodical Supply Service, New Delhi, pp. 61-70.

Misra AK and Pandey BK (1997). Pathogenicity and symptom production of wilt disease of guava by a new potent pathogen Gliocladium roseum. Indian Phytopathological Society-Golden Jubilee International Conference on Integrated Plant Disease Management for Sustainable Agriculture, IARI, New Delhi, Nov.10-15, 319 pp.

Misra AK and Pandey BK (1999). Guava wilt disease - A challenge for the coming millennium. Proc. Nat. Symp. Challenges \& Prospects of Plant Pathology in the coming millennium. Dec. 9-11, 1999 NBRI, Lucknow. pp. 22.

Misra AK and Pandey BK (1999b). Pathogenicity and evaluation of fungicides against guava wilt pathogens. J. Mycol. PI. Pathol. 29: 274-275.

Misra A.K. and Pandey, B.K. (1999d). Natural wilting of guava plants during different months. Indian Phytopath. 52: 312.

Misra AK and Pandey BK (2000a). Pathogenicity and symptom production of wilt disease of guava by a new potent pathogen Gliocladium roseum. Proceedings, Indian Phytopathological Society-Golden Jubilee, International Conference on Integrated Disease Management for Sustainable Agriculture Vol. II Pub. Indian Phytopathological Society, New Delhi, 749-750 pp.

Misra AK and Pandey BK (2000b). Progressive natural wilting of guava plants during different months. Indian Phytopath. 53: 423-427.

Misra AK and Prakash Om (1986). Studies on diseases of fruit crops. Annual Report, CIHNP, Lucknow. 67-68 pp.

Misra AK and Prakash Om (1990). Guava Diseases - (An annotated bibliography 1907-1990). Bishen Singh Mahendra Pal Singh, Dehradun, $132 \mathrm{p}$.

Misra AK and Prasad B (2003). Relative efficacy of different bio-agents for the control of guava wilt. J. Mycol. PI. Pathol. 33: 494.

Misra AK and Prasad D (2004). Aspergillus niger strain AN 17 potent bioagent to control wilt disease and its easy multiplication. Symposium on recent advances in fungal bioagents and their social benefits, $10^{\text {th }}$ Sept. 2004, NBRI, Lucknow. 12 pp.

Misra AK and Shukla SK (2002). Assessment of loss due to Guava wilt around Lucknow. Nat. Seminar on Production and Post-Harvest Technology of Guava. Dept. Hort. CSAUA\&T, Kanpur, 9-10 January, 2002. 34-35 pp.

Misra AK and Singh VK (2005). The CISH, Lucknow, marches towards solving guava wilt and mango malformation. Indian Hortic. (April-June), 50: 25-27.

Misra AK, Prakash Om and Sen B (2000). Biological control of guava wilt by Aspergillus niger strain AN17 (Pusa Mrida). 
Nat. Seminar on Hi-tech Hort. 26-28th June, Bangalore, $149 \mathrm{pp}$.

Misra AK, Pandey BK and Prakash Om (2003b). Wilt of guava, a disease of national importance and possible solutions. Souvenir \& Abstract, Zonal Conference (East Zone), Indian Society of Mycology and Plant Pathology \& Seminar on Plant Diseases of National Importance with Special Reference to Guava Wilt and Mango Malformation. 4-5 th April, 2003. CISH and IISR. Lucknow. 23 pp.

Misra AK, Rajan S, Prasad Babita, Shukla SK and Prasad D (2003c). Resistant source of wilt disease of guava. Souvenir \& Abstract, Zonal Conference (East Zone), Indian Society of Mycology and Plant Pathology \& Seminar on Plant Diseases of National Importance with Special Reference to Guava Wilt and Mango Malformation. 4-5 th April, 2003. CISH and IISR. Lucknow. 51-52 pp.

Misra AK, Prakash Om, Pandey BK, Prasad Babita, Shukla SK and Prasad D (2003d). Biological control of guava wilt. Souvenir \& Abstract, National Symposium on Organic Farming in Horticulture for Sustainable Production. 29-30 th August, 2003. CISH, Lucknow 65 pp.

Misra AK, Prakash Om, Pandey BK, Prasad Babita, Shukla SK and Prasad D (2004). Biological control of guava wilt. In: Organic Farming in Horticulture (Eds. Pathak RK, Kishun Ram, Khan RM and Ram RA). Pub. CISH, Lucknow. 302$305 \mathrm{pp}$.

Misra AK, Prasad D, Prasad Babita and Shukla SK (2004b). Effective management of wilt disease of guava. Souvenir \& Abstract. Natn. Symp. on Crop Surveillance : Disease Forecasting and Management. Indian Phytopathological Society. Feb 19-21, 2004. Division of Plant Pathology, IARI, New Delhi. 92-93 pp.

Mishra RK, Pandey BK, Muthukumar M, Misra AK, Singh V, Mathew AJ, Pathak N and Zeesshan Mohd (2013). Assessment of genetic diversity of Fusarium solani from different agro-ecological regions of India. J. Ecofriendly Agric. 8: 101-107.

Negi SS, Misra AK and Rajan S (2001). Guava wilt. Proc. National Seminar on New Horizon in Production and Post Harvest Management of Tropical and Subtropical Fruits, IARI, New Delhi, held on Dec. 8-9, 1998, Special issue, Indian Journal of Horticulture 54(1\&2), March \& June: 145151.

Normand F (1994). Strawberry guava, relevance for Reunion. Fruits-Paris 49: 217-227.

Pandey RR and Dwivedi RS (1985). Fusarium oxysporum f. sp. psidii as a pathogen causing wilt of guava in Varanasi district in India. Phytopath. Z. 114: 243-248.

Prakash Om, Misra AK and Shukla SK (2002). Penicillium citrinum - a potent pathogen against wilt disease of guava.
Asian Congress of Mycology and Plant Pathology, Oct 14, 2002, Univ. Mysore, Manasgangotri, Mysore, pp. 180.

Prasad D, Shukla SK, Prasad Babita and Misra AK (2003). Effect of intercrop and different doses of NPK on the incidence of guava wilt. Souvenir \& Abstract, Zonal Conference (East Zone), Indian Society of Mycology and Plant Pathology \& Seminar on Plant Diseases of National Importance with Special Reference to Guava Wilt and Mango Malformation. 4-5 $5^{\text {th }}$ April, 2003. CISH and IISR, Lucknow. pp 53.

Prasad N, Mehta PR and Lal SB (1952). Fusarium wilt of guava (Psidium guajava L.) in Uttar Pradesh, India. Nature 169: 753.

Rodriguez FME and Landa JB (1977). Chemical soil disinfection against parasitic nematode in guava nurseries. Centrol Agricola de la Facultod de Cieneias Agricolos 4: 57-77.

Rodrigues NJ, Robbs CF and Yamashino T (1987). A bacterial disease of guava (Psidium guajava) caused by Erwinia psidii sp. nov. Fitopathologia Brasileira 12: 345-350.

Shukla SK, Prasad Babita, Prasad D and Misra AK (2003). A cheap substrate for the mass multiplication of bio-agents of guava wilt. Souvenir \& Abstract, Zonal Conference (East Zone), Indian Society of Mycology and Plant Pathology \& Seminar on Plant Diseases of National Importance with Special Reference to Guava Wilt and Mango Malformation. 4-5 ${ }^{\text {th }}$ April, 2003. CISH and IISR, Lucknow. 54-55 pp.

Singh B and Lal SB (1953). Wilt of guava. Agril. and An. Hus., III: 78-79.

Sohi HS (1983a). Diseases of tropical and subtropical fruits and their control. In: Recent advances in Plant Pathology (Eds. Husain A, Singh K, Singh BP and Agnihotri VP). pp. 7386. Print House, Lucknow, $521 \mathrm{p}$.

Sohi HS (1983b). Studies on wilt disease of guava. Annual Report, Indian Inst. Hort. Res., Hassarghatta, Bangalore, $102 \mathrm{pp}$.

Srivastava AK, Ahmad R, Kumar S and Sukhada Mohandos (2001). Role of VA -Mycorrhiza in the management of wilt disease of guava in the alfivols of Chotanagpur. Indian Phytopath. 54: 78 -81.

Suhag LS (1976). Observations in guava decline in Haryana and its control. Pesticides 10: 42-44.

Tokeshi H, Valdebenito RM and Dias AS (1980). Occurrence of a bacterial disease of guava in Sao Paulo State. Summa Phytopathologica 6: 85-87.

Vestal EF (1941). Text book of Plant Pathology. Kitabistan Allahabad. $406 \mathrm{p}$.

Vos JE, Schoeman MH, Berjak P, Watt MP and Toerien AJ (2000). Acta Hortic. (513) 69-79 pp.

Webber GF (1928). Plant Pathology. Annual Rep., Florida Agric. Univ. Exp. Stat. June 30, 1928. 